\title{
The Effect of Teaching quality and teaching practices on PISA 2012 Mathematics Achievement of Turkish Students
}

\section{Safiye Bilican Demir (id) 1,}

${ }^{1}$ Koceli University, Faculty of Education, Department of Educational Science, Kocaeli, Turkey

\section{ARTICLE HISTORY}

Received: 19 April 2018

Revised: 16 September 2018

Accepted: 20 September 2018

\section{KEYWORDS}

PISA, Mathematical literacy, Teaching quality, Teaching practices, Hierarchical Linear Modeling

\begin{abstract}
The purpose of this research is to explore the relationship mathematics teaching qualification and teaching activities with mathematics scores of 8th grade Turkish students who participated in PISA (Program for International Student Assessment) 2012 using Hierarchical Linear Modeling. PISA 2012 mathematics literacy test and student questionnaire were used to collect data and these were obtained from the official website of PISA. In this study, random effects one-way ANOVA and random coefficient regression model were developed to analyze the data. The results of the research show that there are significant differences in terms of mathematics literacy between schools. It also indicates that while the increase in the student-centered instructions within the context of classroom activities decreased students' mathematics literacy scores, teachers' frequency of activating cognitive processes and a good disciplined environment increased students' mathematics literacy skill. The impacts of significant variables were discussed and implications for further research were provided.
\end{abstract}

\section{INTRODUCTION}

Education policies that aim to raise students who can make independent decisions, develop critical thinking and analytical skills are becoming more important. Therefore, countries participate in international measurement practices where students' achievements in different fields can be assessed (Anderson, Lin, Treagust, Ross \& Yore, 2007). PISA (Program for International Student Assessment) is one of those surveys, which is administered by the OECD for 15-year-old students. PISA application; is a useful tool that can be used to improve quality in education, equality and productivity and is a good predictor of student success, explaining some common features of students, schools and education systems (Schleicher, 2007). Therefore, the examination of PISA results is of great importance in terms of education systems. Since 2000, every three years fifteen-year-old students participate in PISA. Students are

CONTACT: Safiye Bilican Demir $\bigotimes$ safiyebilican@gmail.com $\equiv$ Koceli University, Faculty of Education, Department of Educational Science, Kocaeli, Turkey 
selected randomly from schools and take tests in three main subjects: Reading, mathematics, and science literacy. For each assessment, one of reading, mathematics and science is chosen as the major domain and given greater emphasis. The remaining two areas, the minor domains, are assessed less thoroughly and the PISA 2012 focus was on mathematics literacy (OECD, 2014a).

In parallel with the changing understanding of education systems, PISA's assessment is forward-looking; rather than focusing on students' specific school curriculum, it assesses students' ability to use their knowledge and skills in real-life challenges. This reflects a change in curricular goals and objectives, which are increasingly concerned with what students can do with what they learn at school. For example, PISA 2012 survey is concerned more about how learners can apply their mathematics knowledge in real-life situations, rather than identifying what they know by using formulas or calculations. In this regard, the structure measured in PISA survey is defined as "mathematical literacy".

Mathematical literacy includes the ability to deal with mathematics and to understand how mathematics is firmly embedded in individual's private, academic and social life (OECD, 2014a). Similarly, McCrone and Dossey (2007) have defined mathematical literacy as being able to understand the role of mathematics in the world, make solid judgements and use mathematics in order to address the needs of life. These definitions locate mathematical literacy not only in the academic-school life of the individual, but also in the daily and business life. In accordance with these definitions, PISA is expected to use mathematical skills in situations where students may encounter real-life situations (e.g. shopping, travel, financial calculations or political problems, etc.) other than typical mathematical problems which they come across at school. Students need to use their mathematical skills in solving these problems. Mathematical skills require higher order thinking skills such as inference and modeling of problem and problem solving. So, PISA reports student performance not just as numerical scores, but also in terms of skills, by describing what students who achieve a given level on a PISA scale typically know and can do. (OECD, 2014a).

Raising individuals with mathematics literacy becomes more important as occupations that require abstract thinking skills; graph-reading or making prediction skills in daily life and importance of economic-monetary data increase. International surveys predict an increase of almost $1 \%$ in annual Gross Domestic Product (GDP) growth per capita with half a standard deviation's increase in individual mathematics and science performance (OECD, 2010). Also, mathematical skills are associated with socio-economic well-being. For example, longitudinal research in the UK suggests that people with poor mathematical skills are more than twice as likely as those with better skills to be represented at the lowest level of employment and are at increased risk of poor mental and physical health (Bynner \& Parsons, 2005). So, the aim of mathematics teaching programs is to raise mathematical literate individuals (MEB, 2005).

In addition to students' mathematical literacy, PISA collects data from students and school administrators in the context of possible affective variables (school-class environment, classroom teaching activities, curricula, etc.) that may affect students' cognitive skills. When the relevant literature is examined, it is seen that there are many studies on the student, teacher and school related factors affecting the mathematical literacy of 15 years old Turkish students. In these studies, variables such as region and school type, time to learn mathematics, gender, socio-economic level, attitudes and class-school characteristics showed significant relationships with mathematical literacy (e.g. Aksu, Güzeller, \& Eser, 2017; Akyüz \& Pala, 2010; Berberoğlu \& Kalender, 2005; İlgün-Dibek, 2015; Usta, 2014). As can be seen, the variables that may influence the mathematical literacy of students in PISA are addressed in a very broad context. Because the nature of the teaching and learning process has an increasing emphasis on student achievement and quality of education, the relevance of factors related to 
this process to mathematical literacy has been addressed in this study. Many studies have shown that the mathematics achievement of students is influenced by the learning-teaching environment (e.g. Akyüz \& Berberoğlu, 2010; Bloom, 1976; Eccles \&Roeser, 2011; Hill \& Rowe, 1998; Lamb \& Fullarton 2002; Wentzel et al., 2010). Characteristics of the teachers who carry out teaching in schools have an important and inevitable influence on student achievement. Therefore, teachers are the basic components of education systems. In this case, it is not possible to ignore the quality of teachers when considering the learning of students and how schools can be improved (Blanton et al., 2002; Wayne \& Youngs, 2003). Deal (2010) and Gallagher (2002) indicate that teachers have a high impact on student achievement when differences in student characteristics are controlled. In recent years, studies on teacher qualifications have focused on teachers' behaviors (Darling - Hammond, 2000; Wenglinsky, 2000). Accordingly, in PISA 2012, data were gathered from students about teachers' classroom practices within the context of mathematical teaching activities and teaching quality.

It is inevitable that the practices of teachers and their use of different materials or tools for a certain purpose are the main determinants of student performance. There are studies in the literature on the relationship between students' mathematical achievements and teaching activities. For example, the study by Davis-Langston (2012) examined the relationship between different style of teaching and mathematics success. The results of the research show that there is a meaningful and positive relationship between the teaching style in which that the teacher is the role model and the students are guided and the mathematics success of the students; on the other hand, there is a negative relationship between the teaching style in which the teacher conveys only knowledge as an expert and the mathematical success. Kirkpatrick (2002) showed that teaching activities, such as using materials in class, asking for problems with more than one solution, encouraging students to discuss groups, linking topics, etc., influenced students' mathematics success positively. In the longitudinal study of Palardy and Rumberger (2008) the students were followed from the pre-school period to the end of the fifth grade and the teaching activities revealed that the mathematics achievement of the students were affected.

Another variable discussed in this study is teaching quality. In this context, what kind of problems has emerged in the classroom during mathematics teaching, the ways teachers follow, and emotional and social support and cognitive activation are discussed. Studies of the relationship of these variables to mathematical achievement showed that a positive, nondisordered classroom environment improves mathematics achievement for students (e.g. Akyüz \& Satıc1 2013; İlgün-Dibek, 2015; Sortkær \& Reimer, 2016; Usta, 2014). Tennant and colleagues (2015) suggested that students tend to have better math achievement when teachers focus on helping and guiding them in understanding mathematical concepts and solving questions. As students spend much of their time with their teachers in school, teacher support can be vital to students' academic development. Emotional support domain is defined as teacher-student interactions that promote social connection and cohesion, convey concern for students' feelings and interest in their individuality, and honor students' desire to learn meaningful material and have a say in their learning (Ruzek et al., 2016). Students who are cognitively active and who are involved in the learning-teaching process are more willing to learn and have a positive effect on their success (Archambault, Janosz \& Chouinard, 2012; Baumert \& Kunter, 2013; Davis-Langston, 2012; Kirkpatrick, 2002; Palardy \& Rumberger, 2008).

For many countries, student performance is an important indicator of the quality of education systems. In addition to evaluating the education systems as a whole, assessments are being carried out to determine the success of students at the national and international scale. In this context, international assessments such as PISA, and the performance of students are significant in many countries. Turkey, since 2003, regularly participates in the PISA application. PISA 
results showed that $8^{\text {th }}$ grade Turkish student performance in mathematics was below the international evaluation criteria and the average mathematics literacy level of students in OECD countries, while the third level, the average mathematics literacy level of students in the sample Turkey is second (OECD, 2014b). Similarly, in PISA 2003 where the focus was on mathematics, $75 \%$ of the Turkish students were in the second skill level and below in terms of mathematical literacy performance (EARGED, 2008). The extremely low percentage of students in the upper levels of proficiency samples in Turkey is also a major problem. Since the implementation of PISA 2003, there has been a slight increase in mathematics literacy scores of Turkish students. However, this increase did not affect much on Turkey's place in the rankings (OECD, 2004; OECD, 2014b). This situation necessitates identifying the reasons of the difficulties of Turkish students in terms of mathematical cognitive domain and the variables influencing it. Identifying the factors that influence the development of this skill will provide valuable information to teachers about how to improve this performance. Furthermore, taking opinions of students will provide data in developing teaching programs according to student expectations and in forming appropriate education environments. It would be appropriate to identify teacher behaviors that lead to behavioral changes in teachers' education policies, curricula, or teacher training programs. The aim of this research is to explore the relationship mathematics teaching qualification and teaching activities with mathematics scores of $8^{\text {th }}$ grade Turkish students who participated in PISA 2012 using Hierarchical Linear Modeling.

\section{METHOD}

\subsection{Research design}

The research investigates the performance of the Turkish students who participated in PISA 2012 in the field of mathematics literacy. The studies based on hierarchical linear modeling aim to explore to what extent variables of interpenetrating structures predict other variables. For this reason, the research employs relational survey model.

\subsection{Sample}

The target population was 4848 15-year-old students who participated in PISA 2012 from Turkey. $49 \%$ of the students are female and $51 \%$ are male. The students were selected using two-stage stratified sampling. First, 170 schools were identified and then students were randomly selected from these schools (OECD, 2014a).

\subsection{Instruments}

PISA 2012 mathematics literacy test and student questionnaire were used to collect data and these were obtained from the official website of PISA. The mathematical cognitive test pays attention to the students' ability to analyze mathematical problems in different situations, to interpret the knowledge, to understand cause-effect relationships, and to find relationships between ideas.

Students participating in PISA applications have not responded to all questions of the mathematics literacy test. There are several possible alternative approaches for making this inference. PISA uses the imputation methodology usually referred to as plausible values (PVs). Using item parameters anchored at their estimated values from the international calibration, the plausible values are random draws from the marginal posterior of the latent distribution for each student (OECD, 2014a). In this research, five possible values for mathematical literacy were separately analyzed. The reliability estimates for the cognitive tests were high and the coefficients ranged between 0.88 and 0.90 for Turkey.

The research also used mathematics student data surveys to identify the variables related to student performance. The independent variables were identified using indices variables and 
these were the scales consisting of several questionnaire items to measure teaching quality and teaching practices. Brief descriptions of these indices from PISA technical report are given below (OECD, 2014a):

\section{Teaching quality indice included four scales:}

Cognitive activation strategies (COGACT). Nine items measured cognitive activation in mathematics lessons (e.g. The teacher gives problems that require us to think for an extended time, The teacher helps us to learn from mistakes we have made). Response categories were "Always or almost always", "Often", "Sometimes" and "Never or rarely". All items were reversed

Mathematics teacher support (MTSUP). This scale provides information on mathematics teacher support. There are four items in this scale (e.g. My teacher lets us know we need to work hard, My teacher helps students with their learning). The four response categories vary from "Strongly agree" to "Strongly disagree". All items were reversed.

Classroom management (CLSMAN). This scale provides information on classroom management and consists of four items (e.g. My teacher keeps the class orderly, My teacher starts lessons on time). The four response categories vary from "Strongly agree" to "Strongly disagree". All items except the last one (ST85Q04) were reversed.

Disciplinary climate (DISCLIMA). This scale provides information on disciplinary climate in the classroom based on five items (e.g. There is noise and disorder, Students don't start working for a long time after the lesson begins). The four response categories were "Every lesson", "Most lessons", "Some lessons", to "Never or hardly ever". All items were reversed

The teaching practices items about the frequency of using 13 different teaching practices from the OECD Teaching and Learning International Survey (TALIS) survey were adapted for use in PISA 2012. The items were reframed for use with students and some practices that are specific to mathematics were added. Teaching practices scale indices had three dimension:

Teacher-centered instruction (TCHBEHTD). Five items measured teacher behaviour when giving directed instruction (e. g. The teacher sets clear goals for our learning, The teacher tells us what we have to learn). Response categories were "Every lesson", "Most lessons", "Some lessons" and "Never or hardly ever". All items were reversed.

Teachers' use of formative assessment (TCHBEHFA). Four items measuring teacher behaviour when conducting formative assessment (e.g. The teacher tells me about how well I am doing in my mathematics class, The teacher tells us what is expected of us when we get a test, quiz or assignment). Response categories ranged from "Every lesson" to "Never or hardly ever". All items were reversed.

Teachers' student orientation (TCHBEHSO). Four items measured teacher behaviour when performing student orientation (e.g. The teacher gives different work to classmates who have difficulties learning and/or to those who can advance faster, The teacher asks us to help plan classroom activities or topics.) Response categories were "Every lesson", "Most lessons", "Some lessons" and "Never or hardly ever". All items were reversed.

The reliability estimates for internal consistency of the independent variables were generally high and the Cronbach's alpha ranged between 0.57 and 0.85 for Turkey (OECD, 2014a).

\subsection{Data analysis}

In PISA, sampling was selected from different units such as student, teacher (class) and school. In studies involving such sampling structures, it is assumed that the previous level is not independent of its subsequent levels (Raudenbush \& Bryk, 2002). In terms of validity and 
reliability of the results, it is important to use appropriate analysis methods for such data structures (Moerbeek, Breukelen \& Berger, 2002). For this reason, Hierarchical Linear Models (HLM) which do not ignore the relations between the observation units have been used as a data analysis method in the research. In terms of the independence and homoscedasticity assumptions, the HLM analysis allows determining standard errors and thus provides more reliable results. Furthermore, the final weights of students were included in the analysis. In this study, the following two models were developed to analyze the data:

Random effects one-way ANOVA model. One-way ANOVA Model was used to test whether there was a difference between schools in mathematics literacy. In addition, intracluster correlation coefficient was calculated to understand how much of the variance derived from the variables added to the model

Random coefficient regression model. This model helped identifying the variables included in the student questionnaire and impacted on students' achievement in mathematics literacy. Then, it was calculated to find out the extent these variables explain the percentage change in students' mathematics literacy scores.

\section{FINDINGS}

\subsection{Random effects one-way ANOVA model}

This model determines if there was enough school variance to justify the use of HLM. The general model is represented for mathematics scores of students:

Level $1 \quad(Y i j \mid F / M P V 1-5)=\beta 0 j+r i j$

Level $2 \quad \beta 0 j=\gamma 00+u 0 j$

Expanded model: $Y i j=\gamma 00+u 0 j+r i j$

where $\beta 0 j$ was the intercept and $\gamma 00$ is the average mathematics scores for students. Further, $r i j$ and $u 0 j$ were the random effect terms at student and teacher level models. The results of the one-way ANOVA with Random Effects model were presented in Table 1.

Table 1. Fixed and random effects for mathematics scores in one-way ANOVA model

\begin{tabular}{llllll}
\hline Fixed Effect & Coefficient & SE & t-ratio & df & $\mathrm{p}$ \\
\hline Intercept $\beta_{0 j}$, & & & & \\
$\begin{array}{l}\text { Overall school mean, } \\
\gamma 00,\end{array}$ & 439.79 & 5.77 & 76.14 & 168 & $<0.001$ \\
\hline Random Effect & & Variance & df & $\chi^{2}$ & $\mathrm{p}$ \\
\hline $\begin{array}{l}\text { School mean, } \mathrm{u}_{0 \mathrm{j}} \\
\text { Level } 1 \text { effect, } \mathrm{r}_{\mathrm{ij}}\end{array}$ & 5344.20 & 168 & 4984.20 & $<0.001$ \\
\hline
\end{tabular}

As revealed in Table 1, according one-way ANOVA model, the mathematics scores of students significant differed according to schools and these differences among schools in terms of mathematics scores were also random $\left(\chi^{2}{ }_{168}=4984.20, p<.001\right)$ and overall school mean was 439.79. The variability within the school and between the schools were estimated to be 5344.20 and 3589.84, respectively. In this regard, intraclass correlation was calculated as 0.40 , which indicates that $40 \%$ of the variability in the mathematics scores of students was explained by the mean mathematics achievement of the school. 


\subsection{Random Coefficient Regression Model}

The second model is random coefficient regression model. This model aimed to identify the student level variables that had an effect on mathematics scores of students. The following models were obtained:

\section{Level 1}

$(Y i j \mid F / M P V 1-5)=\beta 0 j+\beta_{1 j}($ COGACT $)+\beta_{2 j}($ DISCLIMA $)+\beta_{3 j}($ TCHBEHSO $)$

\section{Level 2}

$\beta 0 j=\gamma 00+u 0 j$

$\beta 1 j=\gamma 10+u 1 j$

$\beta 2 j=\gamma 20+u 2 j$

$\beta 3 j=\gamma 30+u 3 j$

where $\beta_{0 j}$ is the intercept, $\beta_{1-3 j}$ are slopes or effects of predictors. The term $r i j$ is the random effect for student i nested in teacher $\mathrm{j}$. The error terms were $u_{0 j}-u_{3 j}$ at the models. The results of the random coefficient regression models were presented in Table 2.

Table 2. Fixed and random effects for mathematics scores in random coefficient model

\begin{tabular}{lllllll}
\hline Fixed Effect & Coefficient & $\mathrm{SE}$ & $\mathrm{t}$-ratio & $\mathrm{df}$ & $\mathrm{p}$ & Effect size \\
\hline $\begin{array}{l}\text { Average mathematics } \\
\text { achievement, } \gamma 00\end{array}$ & 444.255 & 5.535 & 80.251 & 168 & $<0.001$ & \\
TCHBEHSO, $\gamma_{30}$ & -9.856 & 1.493 & -6.601 & 50 & $<0.001$ & 0.167 \\
COGACT, $\gamma_{10}$ & 5.624 & 1.265 & 4.445 & 5137 & $<0.001$ & 0.094 \\
DISCLIMA, $\gamma_{20}$ & 4.927 & 1.466 & 3.360 & 59 & 0.002 & 0.084 \\
\hline Random Effect & $\mathrm{SD}$ & Variance & $\chi^{2}$ & $\mathrm{df}$ & $\mathrm{p}$ & \\
\hline INTRCPT1, u0 & 69.27 & 4799.37 & 4588.60 & 168 & 0.000 & \\
level-1, $\mathrm{r}$ & 59.33 & 3520.25 & & & & \\
\hline
\end{tabular}

As it can be seen in Table 2, the findings show that the effects of the teacher behaviors student oriented, teachers' use of cognitive activation strategies and disciplined attitudes towards mathematics scores of students were statistically significant. The remaining variables were removed from the model. Teacher behavior that was perceived to be more students oriented (TCHBEHSO) had the highest correlation with mathematics scores of students. There was a negative significant relationship between these two variables $(\gamma 30=-9.856, S H=1.49, p<0.01)$. If all significant variables were controlled at the model, one-unit increase in the level TCHBEHSO caused 9.85 point decrease in mathematics scores of students. Considering the effect size of TCHBEHSO, an increase of one standard deviation in this variable would result in an decrease of 0.167 standard deviation in their mean scores.

On the other hand, a positive relationship was found between the frequency of the cognitive activation in mathematics lessons and the mathematics scores of students $(\gamma 10=5.624, S E=1.26$, $p<0.01$ ). If all significant variables were controlled in the model, one-unit increase in the level COGACT caused 5.62 point increase in mathematics scores of students. Considering the effect 
size of COGACT, an increase of one standard deviation in this variable would result in an increase of 0.094 standard deviation in their mean scores. Similarly, a better disciplinary climate was positively correlated with the mathematics scores of students $\left(\gamma_{20}=4.92, S E=1.46, p<0.01\right)$. If all significant variables were controlled in the model, one-unit increase in the level DISCLIMA caused 4.92 point increase in mathematics scores of students. Considering the effect size of DISCLIMA, an increase of one standard deviation in this variable would result in an increase of 0.084 standard deviation in their mean scores.

Adding these three variables into student-level analysis reduced school variability from 5344.20 to 3520.25 , which indicated that these variables explained $39.40 \%$ of within school variability in the mathematics scores of students.

\section{DISCUSSION and CONCLUSION}

This research explores the mathematics literacy performance of Turkish students in PISA 2012 within the context of teachers' class activities. HLM analysis shows that there are significant differences in terms of mathematics literacy between schools. It also indicates that while the increase in the student-centered instructions within the context of classroom activities decreased students' mathematics literacy scores, teachers' frequency of activating cognitive processes and a good disciplined environment increased students' mathematics literacy skills.

Studies in the relevant literature also report similar results. For example, many research results in Turkey display a very heterogeneous distribution in terms of the performance of schools (Berberoğlu \& Kalender, 2005; MEB, 2007; 2010; 2011). This heterogeneity can be explained by teacher characteristics as studies show that the main factor determining the quality of education in schools is teachers (e.g. Harris \& Sass, 2011; Hill \& Rowe, 1996; Rowe \& Hill, 1998; Lamb \& Fullarton, 2002). Several studies have concluded that classrooms as well as schools are important and that teacher and classroom variables account for more variance than school variables (Scheerens et al., 1989; Scheerens, 1993). Schmidt et al. (1999) in their comparison of achievement across countries using TIMSS (Trends in International Mathematics and Science Study) data reported that classroom-level differences accounted for a substantial amount of variation in several countries including Australia and the United States. For example, in the United Kingdom, a recent study of 80 schools and 170 teachers measured achievement growth over the period of an academic year, using start-of-year and end-of-year attainment data. Using multi-level modelling techniques, the impact of teachers on achievement growth was measured. They claimed that over 30 per cent of the variance in student progress was due to teachers. They concluded that teacher quality and teacher effectiveness, rather than other classroom, school and student factors, are large influences on student progress (Hay McBer, 2000).

In this study, it was found a negative correlation between the effects of teacher behaviors related to student orientation and student achievement. Student-centered approaches require motivated and self-directed learners (Lee, 2000) and the learning environment should maximize these psychological needs. In this learning environment, teachers shift their roles from "instructors" to "supporters" of a learning process (Schaal \& Bogner, 2005). From a logistic point of view, student-centered approaches might enhance students' motivation and interest and increase their cognitive achievement as outlined above. However, recent studies have linked student centered learning environments not necessarily to an overall high cognitive learning outcome, but rather to conventional approaches (Jones, 2012; Randler \& Bogner, 2002; Schaal \& Bogner, 2005). Many studies comparing teacher-centered and student-centered learning environments produced controversial results with no consistency in the explanation of effects of different learning environments on achievement (Sturm \& Bogner, 2008). Potential reasons for such results could be related to the lack of experience in hands-on activities as well as open or 
learner-centered approaches. These approaches may create unfamiliar environments and cause anxiety which inhibits learner achievement (Kagan \& Fasan, 1988; Randler \& Bogner, 2002). In Turkey, teachers experience problems in adopting student-centered approaches in their classes and need training on assessment and evaluation techniques that align with such approaches (e.g. Gözütok Akgün \& Karacaoğlu 2005; Gelbal \& Kelecioğlu, 2007). Futhermore, according to the results of the Teaching and Learning International Survey (TALIS), there is a negative relationship between class size and frequency of student-centered practices (OECD, 2009). So, teachers may use less student-centered approaches due to the larger classes in Turkey and this result in lower student achievement.

According to the findings of this study, there is a positive relationship between teachers' use of cognitive activation and mathematics achievement. Similarly, in the literature, a positive relationship has been reported between this variable and mathematics achievement (e.g. Baumert \& Kunter, 2013; Kunter et al., 2013; Lipowsky et al., 2009). Further support for this finding comes from TALIS which notes that in order to foster cognitive activity, teachers need to use deep and challenging content (Mayer, 2004). It appears that argumentation and nonroutine problem solving develop pupils' ability to make connections between mathematical facts, procedures, ideas and representations. As students do more cognitive analysis, a conceptual and deeper understanding of the content may be reached (Chi \& Wylie, 2014; Mayer, 2004).

In this study, discipline climate was found to be positively related with their mathematics achievement. This is consistent with the results reported by previous research (e.g. Arum \& Velez, 2012; Ning et al., 2015; Sortkær \& Reimer, 2016; Usta, 2014). It cannot be expected that student achievement is independent of the characteristics of the classroom environment. A classroom which has teacher-student and student-student based communication can provide a safe environment for students and encourage student participation. For an effective classroom management, teachers should control the classroom, diminish the disruptions and be aware of students' behaviors (Brophy, 1986; Peart \& Campbell, 1999). Otherwise, students may feel stressed and will not have the ideal environment for learning and teachers will spend time to deal with disciplinary problems. Accordingly, the division of the lesson may lead to the distraction of the teacher and the student and the reduction of interest (Smith \& Laslett, 1992). Students in classrooms where there is no problem of discipline are more willing to learn, feel more academic and better able to focus on what is taught, which can positively affect mathematical achievements (EARGED, 2010).

When the results of the study are taken into account, it can be argued that a positive learning environment that eliminates attention distracting factors are needed as well as approaches that could increase student participation and prevent undesirable student behaviours should be used. In addition, teachers should use methods and techniques that could stimulate students' cognitive skills. Moreover, results of this study also have some implications for teacher educators. Policy-makers should develop effective teacher training programs.

\section{Acknowledgements}

This study was presented at the IIIrd International Eurasian Educational Research Congress in 31 May- 3 June 2016 in Mugla, Turkey.

\section{ORCID}

Safiye Bilican Demir (D) http://orcid.org/0000-0001-9564-9029 


\section{REFERENCES}

Aksu,G., Güzeller, C.O.,\& Eser, M. T (2017). Analysis of maths literacy performances of students with Hierarchical Linear Modeling (HLM): The Case of PISA 2012 Turkey. Education and Science, 42 (191),247-266.

Akyüz, G., \& Berberoğlu, G. (2010). Teacher and classroom characteristics and their relations to mathematics achievement of the students in the TIMSS, New Horizons in Education, 58(1),77-95.

Akyüz, G., \& Pala, N. M. (2010). PISA 2003 sonuçlarına göre öğrenci ve sınıf özelliklerinin matematik okuryazarlığına ve problem çözme becerilerine etkisi (The effect of student and class characteristics on mathematics literacy and problem solving in PISA 2003). İlkögretim Online, 9(2), 668-678.

Akyüz, G., \& Satıcı, K. (2013). PISA 2003 verilerine göre matematik okuryazarlığının çeşitli değişkenler açısından incelenmesi: Türkiye ve Hong Kong-Çin modelleri (Investigation of the Factors Affecting Mathematics Literacy Using PISA 2003 Results: Turkey and Hong Kong-China). Kastamonu Üniversitesi Kastamonu Ë̆itim Dergisi, 21(2), 503-522.

Anderson, J. O., Lin, H-S., Treagust, D. F., Ross, S. P., \& Yore, L. D. (2007). Using large scale assessment data sets for research in science and mathematics education: Programme for international student assessment (PISA). International Journal of Science and Mathematics Education, 5, 591-614.

Archambault, I., Janosz, M., \& Chouinard, R. (2012). Teacher beliefs as predictors of adolescents' cognitive engagement and achievement in math. The Journal of Educational Research, 105(5), 319-328.

Arum, R., \& Velez, M. (2012). Improving learning environments - school discipline and student achievement in comparative perspective. Stanford: Stanford University Press.

Baumert, J., \& Kunter, M. (2013). The effect of content knowledge and pedagogical content knowledge on instructional quality and student achievement. In M. Kunter, J. Baumert, W. Blum, U. Klusmann, S. Krauss, \& M. Neubrand (Eds.), Cognitive activation in the mathematics classroom and professional competence of teachers: Results from the COACTIV project (pp. 175-206). New York, NY: Springer.

Berberoğlu, G., \& Kalender, İ. (2005). Öğrenci başarısının yıllara, okul türlerine, bölgelere göre incelenmesi: ÖSS ve PISA analizi (Investigation of student achievement across years, school types and regions: The SSE and PISA analyses). Eğitim Bilimleri ve Uygulama, 4(7), 21-35.

Blanton, L. P., Sindelar, P. T., Correa, V., I., Hardman, M., McDonnell, J., \& Kuhel, K. (2002). Conceptions of beginning teacher quality: Models for conducting research. (COPSSE Document Number RS-6E). Gainesville, FL: University of Florida, Center on Personnel Studies in Special Education. Retrieved from http://copsse.education.ufl.edu/copsse/docs/RS-6/1/RS-6.pdf

Bloom, B.S. (1976). Human characteristics and school learning. New York: McGraw-Hill.

Brophy, J. (1986). Teacher behavior and student achievement. American Psychologist, 41(10), 1069-1077. Doi:10.1037/0003-066X.41.10.1069

Bynner J., \& Parsons S. (2005). Does numeracy matter more? London: National Research and Development Centre for adult literacy and numeracy, Institute of Education, University of London. Retrieved from http://discovery.ucl.ac.uk/10004758/1/parsons2006does.pdf

Chi, M. T. H., \& Wylie, R. (2014). The ICAP framework: Linking cognitive engagement to active learning outcomes. Educational Psychologist, 49(4), 219-243. Doi:10.1080/00461520.2014.965823 
Darling-Hammond, L. (2000). Teacher quality and student achievement: A review of state policy evidence. Educational Policy Analysis Archives, 8(1), 1-46. Retrieved from https://epaa.asu.edu/ojs/article/viewFile/392/515

Davis-Langston, C. (2012). Exploring relationships among teaching styles, teachers' perceptions of their self efficacy and students' mathematics achievement. (Doctoral dissertation). Virginia, Liberty University. Retrieved from https://digitalcommons.liberty.edu/doctoral/497

Deal, S. R. (2010). Graduate students' perceptions of teacher effectiveness. The Journal of the Oklahoma Association of Teacher Educators, 14, 9-18. Retrieved from https://files.eric.ed.gov/fulltext/ED524989.pdf\#page=9

EARGED. (2008). PISA'da okuma becerileri, PISA'da matematik okuryazarlığı (Reading skills in PISA, Mathematical literacy in PISA). Retrieved from http://earged.meb.gov.tr/pisa/dokuman/2009/2009pisa.pdf

EARGED (2010). EARGED PISA Bülteni 3. Retrieved from http://yegitek.meb.gov.tr/earged/dosyalar\%5Cpisa\%5Cpisa_bulten3.pdf

Eccles J.S., \& Roeser R.W. (2011). Schools as developmental contexts during adolescence. Journal of Research on Adolescence, 21(1), 225-241. Doi:10.1111/j.1532 7795.2010.00725.x

Gallagher, H. A. (2002, April). The relationship between measures of teacher quality and student achievement: The case of Vaughn elementary. Paper presented at the annual meeting of American Educational Research Association, New Orleans, L. A. Retrieved from https://files.eric.ed.gov/fulltext/ED468254.pdf

Gelbal, S., \& Kelecioğlu, H. (2007). Teachers' proficiency perceptions of about the measurement and evaluation techniques and the problems they confront. Hacettepe University Journal of Education, 33, 135-145.

Gözütok, F. D., Akgün, Ö. E., \& Karacaoğlu, C. (2005). İlköğretim programlarının öğretmen yeterlikleri açısından değerlendirilmesi (Evaluation of primary education programs in terms of teacher competencies). Eğitimde Yansımalar: VIII Yeni İlkögretim Programlarını Değerlendirme Sempozyumu Bildiri Kitabı (ss.17-40), Ankara: Sim Matbaasi.

Harris, D.N., \& Sass, T.R. (2011). Teacher training, teacher quality and student achievement. Journal of Public Economics, 95(7-8), 798-812. Doi: 10.1016/j.jpubeco.2010.11.009

Hay, McBer. (2000). Research into teacher effectiveness: A model of teacher effectiveness. (Report no: 210), Nottingham: Department for Education and Employment. Retrieved from

http://ateneu.xtec.cat/wikiform/wikiexport/_media/formgest/equips_directius/st02/bloc 5/5_rr216investigacio_professors_eficients.pdf

Hill, P.W., \& Rowe, K.J. (1996). Multilevel modelling in school effectiveness research. School effectiveness and school improvement, 7, 1-34.

Hill, P.W., \& Rowe, K.J. (1998). Modelling student progress in studies of educational effectiveness. School effectiveness and school improvement, 9(3), 310-333.

İlgün-Dibek, M. (2015). PISA 2012 matematik okuryazarlı̆̆ ile öğrenme ve öğretme süreci değişkenleri arasındaki ilişkiler (Relationship between learning and teaching variables and PISA 2012 mathematics literacy). Unpublished Master's thesis. Ankara University, Ankara.

Jones T. (2012). Community in the classroom: An approach to curriculum and instruction as a means for the development of student cognitive, social, and emotional engagement in a high school classroom. Educational Perspectives, 44 (1-2), 58-64. 
Kagan, D., \& Fasan, V. (1988). Stress and the environment. College Teaching, 36, 75-80.

Kirkpatrick, N.D (2002). The effects of teacher quality variables on students' mathematics achievement (Unpublished doctoral dissertation), Available from ProQuest Dissertations and Theses database. (UMI No. 3067771)

Kunter, M., Klusmann, U., Baumert, J., Richter, D., Voss, T., \& Hachfeld, A. (2013). Professional competence of teachers: Effects on instructional quality and student development. Journal of Educational Psychology, 105(3), 805-820. Doi: $10.1037 / \mathrm{a} 0032583$

Lamb, S. \& Fullarton, S. (2002). Classroom and teacher effects in mathematics achievement: Results from TIMSS. Australian Journal of Education, 46(2), 154-171. Doi:10.1177/000494410204600205

Lee, C. Y. (2000). Student motivation in the online learning environment. Journal of Educational Media \& Library Sciences, 37(4), 367-375.

Lipowsky, F., Rakoczy, K., Pauli, C., Drollinger-Vetter, B., Klieme, E., \& Reusser, K. (2009). Quality of geometry instruction and its short-term impact on students' understanding of the Pythagorean Theorem. Learning and Instruction, 19(6), 527-537. Doi: 10.1016/j.learninstruc. 2008.11.001

Mayer, R. E. (2004). Should there be a three-strikes rule against pure discovery learning?. American Psychologist, 59(1), 14-19. Doi: 10.1037/0003-066X.59.1.14

McCrone, S., \& Dossey, J. A. (2007). Mathematical literacy-It's become fundamental. Principal Leadership, 7(5), 32-37.

MEB. (2005). İlköğretim matematik 6-8. sınıflar öğretim programı kitabı (Primary Mathematics 6-8. Classes Curriculum Book). Ankara: Milli Eğitim Bakanlığı Talim ve $\begin{array}{llll}\text { Terbiye } & \text { Kurulu } & \text { Başkanlığı. } & \text { Retrieved }\end{array}$ http://talimterbiye.mebnet.net/Ogretim\%20Programlari/ortaokul/20102011/Matematik\%20-\%206\%20.pdf

MEB. (2007). PISA 2006 Uluslararası Öğrenci Değerlendirme Projesi, Ulusal Ön Rapor (Program for international student assessment PISA 2006, national report). Ankara: Eğitim Araştırma ve Geliştirme Dairesi Yayınları. Retrieved from http://www.earged.meb.gov.tr/ dosyalar/dokumanlar/uluslararasi/PISA2006.pdf

MEB. (2010). PISA 2009 uluslararasi ögrenci dĕgerlendirme projesi, ulusal ön rapor (Program for international student assessment PISA 2009, national report). Ankara: Eğitim Araştırma ve Geliştirme Dairesi Yayınları. Retrieved from http://pisa.meb.gov.tr/wp-content/uploads/2013/07/pisa-2009-ulusal-on-rapor.pdf

MEB. (2011). TIMSS 2007 ulusal matematik ve fen raporu 8. Sinfflar (TIMSS 2007 national mathematics and science report Grades 8). Ankara: EARGED. Retrieved from http://timss.meb.gov.tr/wp-content/uploads/timss_2007_ulusal_raporu.pdf

Moerbeek, M., Breukelen, G.J.P., \& Berger, M.P.F. (2002). A comparison between traditional methods and multilevel regression for the analysis of multicenter intervention studies. Journal of Clinical Epidemiology, 56, 341-350.

Ning, B., Van Damme, J., Van Den Noortgate, W., Yang, X., \& Gielen, S. (2015). The influence of classroom disciplinary climate of schools on reading achievement: A cross country comparative study. School Effectiveness and School Improvement, 26(4), 1-26. Doi:10.1080/09243453.2015.1025796

OECD. (2004). Learning for tomorrow's world. First results from PISA 2003. Paris: OECD Publishing. 
OECD (2009). Creating effective teaching and learning environments first results from TALIS. Paris: OECD $\quad$ Publication. $\quad$ Retrieved from http://www.oecd.org/education/school/43023606.pdf

OECD. (2010). The high cost of low educational performance: The long-run economic impact of improving educational outcomes. Paris: OECD Publication. Retrieved from https://www.oecd.org/pisa/44417824.pdf

OECD. (2014a). PISA 2012 Technical Report. Paris: OECD Publication. Retrieved from https://www.oecd.org/pisa/pisaproducts/PISA-2012-technical-report-final.pdf

OECD. (2014b). PISA 2012 Results: What students know and can do-Student performance in mathematics, reading and science (Volume I, Revised edition, February 2014). Paris: OECD Publication. Retrieved from https://www.oecd.org/pisa/keyfindings/pisa 2012results-volume-I.pdf

Palardy, G. J., \& Rumberger, R. W. (2008). Teacher effectiveness in the first grade: The importance of background qualifications, attitudes, and instructional practices for student learning. Educational Evaluation and Policy Analysis,30, 111-140.

Peart, N. A., \& Campbell, F. A. (1999). At-risk students' perceptions of teacher effectiveness. Journal for a Just and Caring Education, 5(3), 269-284.

Randler, C., \& Bogner, F. X. (2002). Comparing methods of instruction using bird species identification skills as indicators. Educational Research, 36(4), 181-188.

Raudenbush, S. W., \& Bryk, A. S. (2002). Hierarchical linear models: Applications and data analysis methods. London: Sage.

Rowe, K.J., \& Hill, P.W. (1998). Modelling educational effectiveness in classrooms: The use of multi-level structural equations to model students' progress. Educational Research and Evaluation, 4(4), 307-347.

Ruzek, E. A., Hafen, C. A., Allen, J. P., Gregory, A., Mikami, A. Y., \& Pianta, R. C. (2016). How teacher emotional support motivates students: The mediating roles of perceived peer relatedness, autonomy support, and competence. Learning and Instruction, 42, 95103. doi: 10.1016/j.learninstruc.2016.01.004

Schaal, S., \& Bogner, F. X. (2005). Human visual perception-Learning at workstations. Journal of Biological Education, 40 (1), 32-37. Doi:10.1080/00219266.2005.9656006

Scheerens, J. (1993). Basic school effectiveness research: Items for a research agenda. School Effectiveness and School Improvement, 4(1), 17-36. Doi:10.1080/0924345930040102

Scheerens, J., Vermeulen, C. J. A. J., \& Pelgrum, W. J. (1989). Generalizability of instructional and school effectiveness indicators across nations. International Journal of Educational Research, 13(7), 789 - 799.

Schleicher, A. (2007). Can competencies assesed by PISA be considered the fundemental school knowledge:15-year-olds should possess? Journal of Educational Change, 8(4), 349-357.

Schmidt, W. H., McKnight, C. C., Cogan, L. S., Jakwerth, P. M., \& Houang, R. T. (1999). Facing the consequences: Using TIMSS for a closer look at U.S. mathematics and science education. Dordrecht: Kluwer.

Smith, C.J., \& Laslett, R. (1992). Effective Classroom Management. United States: Routlage.

Sortkær, B., \& Reimer, D (2016). Disciplinary climate and student achievement: evidence from schools and classrooms. Aarhus: Danish School of Education, Aarhus University. Retrieved from http://edu.au.dk/fileadmin/edu/Udgivelser/Eboeger/Working_papers_DPU_2016 Disciplinary_Climate_and_Student_Achievement.pdf. ID: 2347254578 
Sturm, H., \& Franz X. Bogner, F.X. (2008) Student-oriented versus teacher-centred: The effect of learning at workstations about birds and bird flight on cognitive achievement and motivation. International Journal of Science Education, 30(7), 941-959, DOI: 10.1080/09500690701313995

Tennant, J. E., Demaray, M. K., Malecki, C. K., Terry, M. N., Clary, M., \& Elzinga, N. (2015). Students' ratings of teacher support and academic and social-emotional wellbeing. School Psychology Quarterly, 30(4), 494-512. https://doi.org/10.1037/spq0000106

Usta, H.G. (2014). PISA 2003 ve PISA 2012 Matematik okuryazarlığ üzerine uluslararası bir karşılaştırma: Türkiye ve Finlandiya (PISA 2003 and PISA 2012 mathematics literacy on an international comparison: Turkey and Finland). Unpublished Master's thesis. Ankara University, Ankara.

Wayne, A. J., \& Youngs, P. (2003). Teacher characteristics and student achievement gains: A review. Review of Educational Research, 73(1), 89-122.

Wenglinsky, H. (2000). How teaching matters: Bringing the classroom back into discussions of teacher quality. Princeton. (ERIC Document Reproduction Service No ED447128).NJ: Educational Testing Service, Policy Information Center. Doi:10.1177/019263650408863811

Wentzel K.R., Battle A., Russell S.L., \& Looney L.B. (2010). Social supports from teachers and peers as predictors of academic and social motivation. Contemporary Educational Psychology, 35(3), 193-202. Doi: 10.1016/j.cedpsych.2010.03.002 